\title{
Pencil-core granuloma*
}

\author{
Maraya de Jesus Semblano Bittencourt ${ }^{1}$ \\ Jorge Nazareno da Silva Barros Junior ${ }^{1}$
}

\author{
Josie Eiras Bisi dos Santos ${ }^{1}$ \\ Ellen Maria Sampaio Xerfan ${ }^{1}$
}

\section{DOI: http:/ / dx.doi.org/10.1590/abd1806-4841.20176011}

Abstract : Pencil core granulomas are still infrequently reported in the literature. A 67-year-old woman presented with a $4 \mathrm{~mm}$ hard blue subcutaneous nodule on the forehead. She remembered being injured with a pencil tip about 60 years before. The subcutaneous nodule was excised, which microscopically revealed a foreign body reaction with histiocytes containing fragmented coarse black particles. We diagnosed pencil-core granuloma based on the patient's history of pencil tip injury and histological examination findings.

Keywords: Giant cells, foreign-body; Graphite; Granuloma, Foreign-body; Foreign bodies

Graphite pencils - whose cores are mainly composed of graphite, clay, and various waxes - are still commonly used. Accidents caused by these materials are a common occurrence, especially in childhood. However, granulomas secondary to a retained pencil core are rarely reported in the literature. ${ }^{1-10}$

A 67-year-old woman reported that she suffered a penetrating injury caused by a pencil on the forehead when she was 7 years old. Since then, she had a painless bluish-gray subcutaneous nodule, measuring about $4 \mathrm{~mm}$. She reported some recently mild episodes of

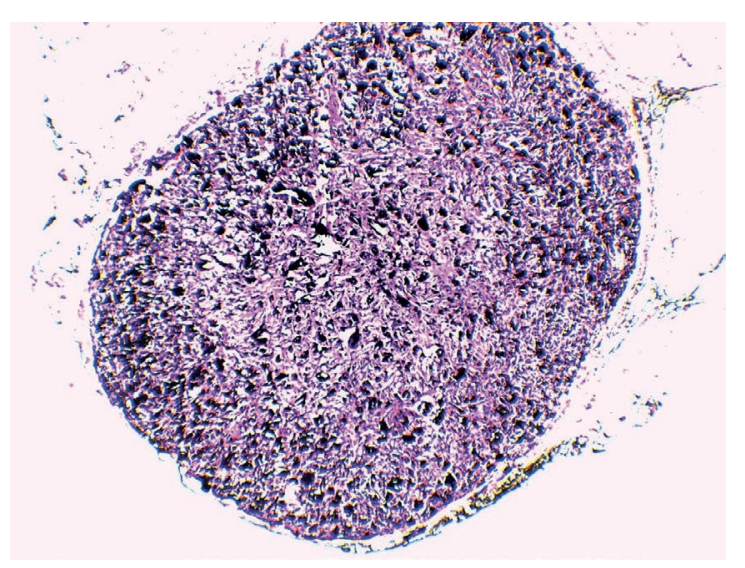

FIGURE 1: Nodular dermal proliferation comprising foreignbody-type multinucleated giant cells and abundant histiocytes containing coarse black particles (Hematoxylin \& eo$\sin X 40$ ) pain to the touch after the lesion was handled. Histopathological examination of the excised lesion showed a foreign body granulomatous reaction consisting of multinucleated histiocytes and abundant coarse black particules (Figures 1 and 2).

Graphite in a pencil is generally sealed. Once it disintegrates to a critical size in the skin, the particles are dispersed in the interstice and induce a granulomatous reaction. ${ }^{1}$ Clinical aspects of this granuloma may resemble those of malignant melanoma and blue nevus because most cases show a hyperpigmented nodule

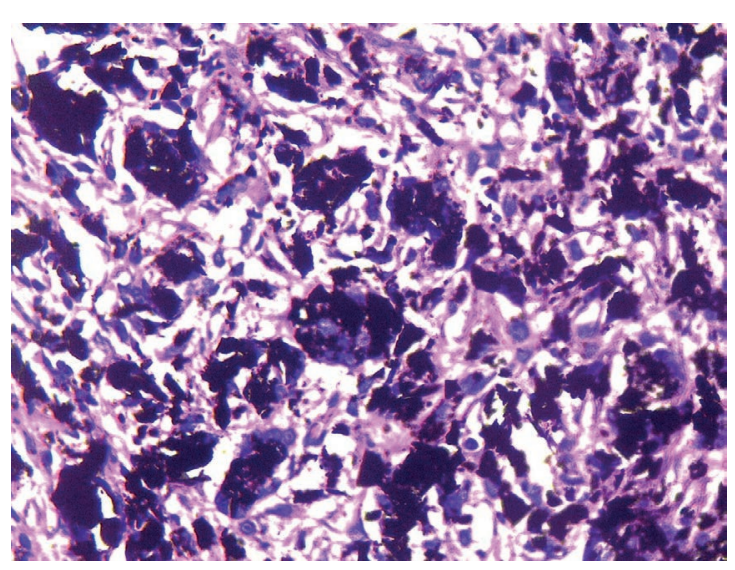

FIGURE 2: Detail of the foreign body with histiocytes containing coarse black particles (Hematoxylin \& eosin, X400).

Received on 07.05.2016

Approved by the Advisory Board and accepted for publication on 01.08.2016

* Work performed at a private clinic - Belém (PA), Brazil.

Financial support: none.

Conflict of interest: none.

1 Department of Dermatopathology at Universidade Federal do Pará (UFPA) - Belém (PA), Brazil.

@2017 by Anais Brasileiros de Dermatologia 
secondary to the pencil core retained. ${ }^{1-3}$ Previously, the longest evolution time described in the literature was 58 years; in the present case, it was 60 years. The sites most affected by this reaction are possibly the limbs because they are areas that are more exposed to mechanical traumas. Just a few cases of granulomas affecting the face were reported, as in the present case. Less frequent mechanical stimuli on the face compared to the limbs may be the reason for its rare location. ${ }^{1,5}$ In a case of giant pencil core granuloma on the palm, the authors considered the theory that repetitive mechanical stimuli caused the foreign body reaction and accelerated the growth of the granuloma. ${ }^{4}$ A previous report suggested faster growth of lesions and a higher degree of tissue injury by colored pencil when compared with non-colored graphite pencils. ${ }^{5}$ The present report supports the drawn-out nature of these reactions. Therefore, this diagnosis should be considered for long-standing pigmented skin lesions.

\section{REFERENCES}

1. Fukunaga Y, Hashimoto I, Nakanishi H, Seike T, Abe Y, Takaku M. Pencil-core granuloma of the face: Report of two rare cases. J Plast Reconstr Aesthet Surg. 2011;64:1235-7.

2. Taylor B, Frumkin A, Pitha JV. Delayed reaction to "lead" pencil simulating melanoma. Cutis. 1988;42:199-201.

3. Lim GF, Lim SJ, Mahmoodi M, Radfar A. Enlarging hyperpigmented nodule on the right calf. Pencil-core granuloma. Int J Dermatol. 2013;52:933-4.

4. Yoshitatsu S, Takagi T.. A case of giant pencil-core granuloma. J Dermatol. 2000;27:329-32.

5. Shido H, Tamada I. Colored pencil-core granuloma on the forehead. Pediatr Dermatol. 2015;32:e58-9.

6. Aswani VH, Kim SL. Fifty-three years after a pencil puncture wound. Case Rep Dermatol. 2015;7:303-5

7. Granick MS, Erickson ER, Solomon MP. Pencil-core granuloma. Plast Reconstr Surg. 1992;89:136-8.

8. Yoshitatsu S, Takagi T. A case of giant pencil-core granuloma. J Dermatol. 2000;27:329-32.

9. Nelson EW, DeHart MM, Christensen AW, Smith DK. Magnetic resonance imaging characteristic of a lead pencil foreign body in the hand. J Hand Surg Am. 1996;21:100-3.

10. Gormley RH, Kovach SJ 3rd, Zhang PJ Role for trauma in inducing pencil "lead" granuloma in the skin. J Am Acad Dermatol. 2010;62:1074-5.

\section{MAILING ADDRESS: \\ Maraya de Jesus Semblano Bittencourt \\ Tv. Dom Romualdo de Seixas, 236 \\ Edifício Saúde Center, sala 20 - Umarizal \\ 66050-110 - Belém, PA \\ Brazil \\ E-mail: marayabittencourt@hotmail.com}

How to cite this article: Bittencourt MJS, Santos JEB, Barros Junior JNS, Xerfan EMS. Pencil-core granuloma. An Bras Dermatol. 2017;92(4):5789 . 